\title{
Hypovitaminosis D Is Associated With Visceral Adiposity, High Levels of Low-Density Lipoprotein and Triglycerides in Alternating Shift Workers
}

\author{
Aline Priscila Batista ${ }^{a}$, Ticiana Vazzoler Ambrosim ${ }^{b}$, Raimundo Marques do Nascimento Neto ${ }^{c}$, \\ Fausto Aloisio Pedrosa Pimentac ${ }^{\mathrm{c}}$, Silvia Nascimento de Freitas ${ }^{\mathrm{b}}$, Marcio Weissheimer Lauria ${ }^{\mathrm{d}}$, \\ George Luiz Lins Machado-Coelho, c, e
}

\begin{abstract}
Background: Studies suggest that there is a strong association between low vitamin D levels and cardiovascular disease (CVD) and its risk factors (RFs). Hypovitaminosis D $(25(\mathrm{OH}) \mathrm{D}<30 \mathrm{ng} / \mathrm{mL}$ or 75 $\mathrm{nmol} / \mathrm{L})$ is a recent public health problem that has reached different populations. The objective of the study was to investigate whether hypovitaminosis D is an additional mechanism to explain the disturbances in the lipid profile as well as the excess of abdominal fat presented by alternating shift workers of a mining company in the region of Inconfidentes, Minas Gerais, Brazil.
\end{abstract}

Methods: A cross-sectional study was conducted in a sample of 391 adult males, aged 20 - 57 years old and working alternating shifts, who had at least one risk criterion for CVD. Demographic, behavioral, clinical, and anthropometric and body composition variables were obtained. A blood sample was drawn for determining $25(\mathrm{OH})$ $\mathrm{D}$, parathyroid hormone intact molecule, lipid profile, blood glucose, insulin, C-reactive protein, and adipokines.

Results: The average age of the 391 study participants was $36.1 \pm 7.3$ years. The percentage of hypovitaminosis D and dyslipidemia was $73 \%$ and $74.2 \%$, respectively. Excess visceral fat was significant in the hypovitaminosis D group, with an odds ratio (OR) of $2.4(95 \%$ confidence interval (CI): 1.1 - 5.2). Dyslipidemia showed 25(OH)D levels significantly lower (OR: 2.7, 95\% CI: 1.6 - 4.3) than in individuals with normal levels of cholesterol and fractions, and triglycerides. After adjusted the analysis by age and seasonality, the vitamin levels had a significant inverse association and dose-dependent with lowdensity lipoprotein (OR: 5.9), triglycerides (OR: 2.3) and visceral fat

Manuscript accepted for publication April 04, 2016

${ }^{a}$ Nucleo de Pesquisa em Ciencias Biologicas, Federal University of Ouro Preto, Ouro Preto, Brazil

${ }^{b}$ School of Nutrition, Federal University of Ouro Preto, Ouro Preto, Brazil 'School of Medicine, Federal University of Ouro Preto, Ouro Preto, Brazil ${ }^{\mathrm{d}}$ School of Medicine, Federal University of Minas Gerais, Belo Horizonte, Brazil

${ }^{e}$ Corresponding Author: George Luiz Lins Machado-Coelho, Nucleo de Pesquisa em Ciencias Biologicas, Federal University of Ouro Preto, Ouro Preto, Brazil.Email: gmcoelho@medicina.ufop.br

doi: http://dx.doi.org/10.14740/jem340w area (OR: 2.4).

Conclusion: Hypovitaminosis D and dyslipidemia were found in the majority of our mining company shift workers. Furthermore, excess visceral adiposity, hypertriglyceridemia and high low-density lipoprotein cholesterol levels are strong predictors of hypovitaminosis D.

Keywords: Alternating shift workers; Occupational health; Lowdensity lipoprotein; Triglycerides; Atherosclerosis; Visceral fat; Hypovitaminosis D; Metabolic syndrome

\section{Introduction}

Vitamin D comprises a group of secosteroid molecules, classically acting on bone metabolism and calcium homeostasis. Calcidiol $(25(\mathrm{OH}) \mathrm{D})$ is the biochemical marker that best reflects vitamin $\mathrm{D}$ status, and the active metabolite, calcitriol $\left(1,25(\mathrm{OH})_{2} \mathrm{D}_{3}\right)$, acts as a hormone steroid [1]. This exerts its biological effect via the nuclear receptor (VDR), which is widely distributed in tissues, and provides a range of physiological effects in the body [2]. Humans get vitamin D through the skin by exposure to solar ultraviolet B rays (UVB) and dietary intake, which meets only $10-20 \%$ of the body's needs [3].

Observational studies suggest there is a strong vitamin D deficiency associated with cardiovascular disease (CVD) and its risk factors (RFs), such as dyslipidemia and adiposity. Several authors [4-8] observed that the low levels of vitamin D increases the risk of CVD and its FRs, but the mechanisms that explain this association are still being explored. Clinical and experimental studies are needed to determine an appropriate vitamin $\mathrm{D}$ status that could contribute to the prevention of CVD.

According to Ding et al (2012) [9], the connection of vitamin $\mathrm{D}$ with adipose tissue is due to signaling through the VDR, which inhibits adipogenic transcription factors and lipid accumulation during adipocyte differentiation. The association between increased adiposity and reduced serum calcidiol has been reported for more than three decades, suggesting, as the primary hypothesis, the facility to be stored in adipose tissue due to lipid solubility [10]. Thus, the low bioavailability of calcidiol compromises the function of adipose tissue. 
Hypovitaminosis D $(25(\mathrm{OH}) \mathrm{D}<30 \mathrm{ng} / \mathrm{mL}$ or $75 \mathrm{nmol} / \mathrm{L})$ is a recent public health problem, which has been reaching different populations in different age groups around the world [11]. Advanced age, female gender, higher latitude, air pollution, winter season, darker skin pigmentation, less sunlight exposure, dietary habits, and the absence of vitamin D fortification in foods are the main factors that are significantly associated with low levels of 25(OH)D [12].

A study by Ward et al (2011) was the first to draw attention to the risk of vitamin D deficiency according to some occupational standards, such as night shifts and long hour shifts [13]. Hypovitaminosis D primarily accompanies individuals who have changes in one or more components of the lipid profile [14-16], and are overweight or obese [17]. However, among the studies of shift workers that evaluated the association with cardiovascular RFs, few paid attention to the relationship of vitamin $\mathrm{D}$ with changes in the levels of dyslipidemia components and high adiposity affecting this occupational group.

Although studies show the association of shift work with an increased risk for CVD [18, 19], the pathways that could explain the development of these RFs are not yet fully known and little is known about their manifestations in alternating shift workers in the mining area. Therefore, this study aimed to assess whether hypovitaminosis D is an additional mechanism to explain lipid profile disorders and excess abdominal adiposity, represented by the volume of visceral fat presented by alternating shift workers of a mining company operating in the Inconfidentes region, located in the state Minas Gerais, in southeastern Brazil.

\section{Materials and Methods}

A cross-sectional study was carried out with 391 adult men, off-road truck drivers operating at four mines in a mining company located in the region of Inconfidentes, Mariana and Ouro Preto municipalities, in the State of Minas Gerais, Brazil. Men with kidney disease or chronic liver disease and using statin and/or vitamin D supplements were excluded. The drivers work under conditions of alternating shifts, with clockwise rotation (morning/afternoon/evening), including 6 and $12 \mathrm{~h}$ of rest.

The socio-demographic characteristics were obtained by means of a semi-structured self-administered questionnaire. Skin color was self-reported. To determine alcohol consumption, we used the "Alcohol Use Disorders Identification Test - AUDIT" (WHO, 1992) [20] with individuals classified as low-risk consumption and risk drinking. Smoking was evaluated by "Fagerstrom Nicotine Dependence Test - FTND" [21] with individuals classified as smokers and non-smokers. The level of physical activity was measured by version 8 of the "International Physical Activity Questionnaire - IPAQ" [22].

Three blood pressure measurements were performed with automatic digital blood pressure monitor HEM - 705CP ${ }^{\circledR}$ device (Omron). The worker sat with the cuff pressure firmly set and adjusted and kept at heart level. The interval between measurements was $1-2 \mathrm{~min}$. At the end of the measurements, the lower value blood pressure measurement was considered.
Systolic blood pressure $(\mathrm{SBP}) \geq 140 \mathrm{~mm} \mathrm{Hg}$ and/or diastolic blood pressure (DBP) $\geq 90 \mathrm{~mm} \mathrm{Hg}$ and/or use of antihypertensive medication were classified as arterial hypertension [23]. Alternatively, we adopted a lower cut-off point to classify blood pressure as "changed", for those with SBP $\geq 130 \mathrm{~mm}$ $\mathrm{Hg}$ or $\mathrm{DBP} \geq 85 \mathrm{~mm} \mathrm{Hg}$ or use of antihypertensive.

Body weight, body fat percentage $(\mathrm{BF} \%)$, and the visceral fat area (VFA) were obtained by bioimpedance (BIA), the segmented body composition monitor InBody model $720^{\circledR}$ (Biospace Co. Ltd. Factory) and height was measured in centimeters by Estadiometer digital HM-210 model $\mathrm{D}^{\circledR}$ (Charder). The body mass index (BMI) was calculated using the formula weight $(\mathrm{kg}) /$ height $^{2}(\mathrm{~m})$ and classified into pre-obese (BMI: 25 - $\left.29.9 \mathrm{~kg} / \mathrm{m}^{2}\right)$ and obesity $\left(\mathrm{BMI} \geq 30 \mathrm{~kg} / \mathrm{m}^{2}\right)$ according to the World Health Organization (2000) [24]. Waist circumference (WC), hip circumference (HC) and circumference neck (NC) were obtained with a simple, inelastic tape measure [25]. The waist/hip ratio (WHR) was calculated by the $\mathrm{WC}_{(\mathrm{cm})} / \mathrm{HC}_{(\mathrm{cm})}$ ratio and the waist/height ratio (WHER) was calculated by the $\mathrm{WC}_{(\mathrm{cm})} /$ height $_{(\mathrm{m})}$ ratio. Blood collection was performed after fasting for $12 \mathrm{~h}$ and held in the collection tube S-Monovette ${ }^{\circledR}$ (Sarstedt) of $7.5 \mathrm{~mL}$ without anticoagulant to obtain serum for biochemical analysis and S-Monovette ${ }^{\circledR}$ tube (Sarstedt) $2.7 \mathrm{~mL}$ containing fluoride to obtain plasma for blood glucose level.

The concentration of vitamin D $(25(\mathrm{OH}) \mathrm{D})$ was determined in Liaison ${ }^{\circledR}$ apparatus (DiaSorin), a chemiluminescence immune analyzer. The levels of parathyroid hormone intact molecule (iPTH) were determined by electrochemiluminescence in Cobas apparatus E 6000/601 ${ }^{\circledR}$ (Roche). Serum levels of vitamin D were classified according to Maeda et al (2014) [26] as sufficient $(25(\mathrm{OH}) \mathrm{D} \geq 30 \mathrm{ng} / \mathrm{mL}$ or $75 \mathrm{nmol} / \mathrm{L})$ and low $(25(\mathrm{OH}) \mathrm{D}<30 \mathrm{ng} / \mathrm{mL}$ or $75 \mathrm{nmol} / \mathrm{L})$. iPTH levels were ranked according to the respective kit manufacturer as normal $(\leq 65 \mathrm{pg} / \mathrm{mL})$ and high $(>65 \mathrm{pg} / \mathrm{mL})$.

Dosages of triglycerides (TG), total cholesterol (TC), and high-density lipoprotein (HDL-c) fraction were determined by enzyme-colorimetric method (Human Brazil, Itabira, Brazil) in the Auto-Analyzer Chemwell R6 ${ }^{\circledR}$ (Technology Awareness). Low-density lipoprotein cholesterol (LDL-c) and very low-density lipoprotein cholesterol (VLDL-c) fractions were obtained by mathematical calculation using the Friedewald formula for triglyceride concentration less than or equal to 400 $\mathrm{mg} / \mathrm{dL}$ [27]. The components of the lipid profile were classified according to the V Brazilian Guidelines for dyslipidemia and prevention of atherosclerosis [28]. Dyslipidemia was considered when one or more criteria were met according to NCPE/ ATP III (2002) [29]: total cholesterol $\geq 200 \mathrm{mg} / \mathrm{dL}$, LDL-c $\geq$ $130 \mathrm{mg} / \mathrm{dL}, \mathrm{HDL}-\mathrm{c}<40 \mathrm{mg} / \mathrm{dL}, \mathrm{TG} \geq 150 \mathrm{mg} / \mathrm{dL}$ and VLDL-c $\geq 30 \mathrm{mg} / \mathrm{dL}$.

Fasting blood glucose was determined by enzymatic colorimetric analysis (Bioclin, Belo Horizonte, Brazil) in CM20 apparatus (Wiener). Blood glucose was classified according to the IDF (2005) [30] as normal $(<100 \mathrm{mg} / \mathrm{dL})$ and impaired $(\geq$ $100 \mathrm{mg} / \mathrm{dL})$.

Fasting insulin levels $(\mathrm{pg} / \mathrm{mL})$, adiponectin $(\mathrm{pg} / \mathrm{mL})$, and C-reactive protein $(\mathrm{mg} / \mathrm{L})(\mathrm{CRP})$ were determined by Milliplex ${ }^{\circledR}$ Human Panel adipokine magnetic bead method. Insulin and adiponectin levels were classified according to the values 
Table 1. Distribution of Categories of Demographic and Behavioral Variables According to the Levels of 25(OH)D

\begin{tabular}{|c|c|c|c|c|c|c|}
\hline Variables & $\begin{array}{l}25(\mathrm{OH}) \mathrm{D}<30 \mathrm{ng} / \\
\mathrm{mL}(75 \mathrm{nmol} / \mathrm{L})\end{array}$ & $\begin{array}{l}25(\mathrm{OH}) \mathrm{D} \geq 30 \mathrm{ng} / \\
\mathrm{mL}(75 \mathrm{nmol} / \mathrm{L})\end{array}$ & Total & $\mathbf{n}$ & Odds ratio $(95 \%$ CI $)$ & P value* \\
\hline Age (years), mean \pm SD & $36.7 \pm 7.5$ & $34.7 \pm 6.4$ & $36.1 \pm 7.3$ & 391 & - & 0.016 \\
\hline Skin color & & & $\%$ & & & 0.835 \\
\hline White & $100(35.1)$ & $36(34)$ & 34.8 & 136 & 1.0 & \\
\hline Non-white & $185(64.9)$ & $70(66)$ & 65.2 & 255 & $0.95(0.59-1.52)$ & \\
\hline Total & & & & 391 & & \\
\hline Education & & & $\%$ & & & 0.175 \\
\hline$\leq 8$ years & $32(11.2)$ & $7(6.6)$ & 10.0 & 39 & 1.0 & \\
\hline$>8$ years & $253(88.8)$ & $99(93.4)$ & 90.0 & 352 & $0.56(0.24-1.31)$ & \\
\hline Total & & & & 391 & & \\
\hline Time spent in shift work & & & $\%$ & & & 0.427 \\
\hline$\leq 5$ years & $135(47.4)$ & $55(51.9)$ & 48.6 & 190 & 1.0 & \\
\hline$>5$ years & $150(52.6)$ & $51(48.1)$ & 51.4 & 201 & $1.19(0.76-1.87)$ & \\
\hline Total & & & & 391 & & \\
\hline Seasonality & & & $\%$ & & & $<0.0001$ \\
\hline Spring & $221(77.5)$ & $61(57.5)$ & 72.1 & 282 & 1.0 & \\
\hline Summer & $64(22.5)$ & $45(42.5)$ & 27.9 & 108 & $0.72(0.68-0.77)$ & \\
\hline Total & & & & 391 & & \\
\hline Smoking & & & $\%$ & & & 0.183 \\
\hline No & $220(82.1)$ & $87(87.9)$ & 83.7 & 307 & 1.0 & \\
\hline Yes & $48(17.9)$ & $12(12.1)$ & 16.3 & 60 & $1.58(0.80-3.12)$ & \\
\hline Total & & & & 367 & & \\
\hline Alcohol consumption & & & $\%$ & & & 0.135 \\
\hline Low risk & $246(86.3)$ & $85(80.2)$ & 84.7 & 331 & 1.0 & \\
\hline Risk & $39(13.7)$ & $21(19.8)$ & 15.3 & 60 & $0.64(0.35-1.15)$ & \\
\hline Total & & & & 391 & & \\
\hline Physical activity & & & $\%$ & & & 0.103 \\
\hline$\geq 3$ days/week & $42(14.7)$ & $9(8.5)$ & 87.0 & 340 & 1.0 & \\
\hline$<3$ days/week & $243(85.3)$ & $97(91.5)$ & 13.0 & 51 & $1.86(0.87-3.97)$ & \\
\hline Total & & & & 391 & & \\
\hline Hypertension $^{\mathrm{a}}$ & & & $\%$ & & & 0.057 \\
\hline No & $90(33.6)$ & $23(23.2)$ & 69.2 & 113 & 1.0 & \\
\hline Yes & $178(66.4)$ & $76(76.8)$ & 30.8 & 254 & $0.6(0.35-1.01)$ & \\
\hline Total & & & & 367 & & \\
\hline Dyslipidemia $^{b}$ & & & $\%$ & & & $<0.0001$ \\
\hline No & $58(20.4)$ & $43(40.6)$ & 25.8 & 101 & 1.0 & \\
\hline Yes & $227(79.6)$ & $63(59.4)$ & 74.2 & 290 & $2.7(1.6-4.3)$ & \\
\hline Total & & & & 391 & & \\
\hline
\end{tabular}

aSystolic blood pressure $\geq 140 \mathrm{~mm} \mathrm{Hg}$ and diastolic blood pressure $\geq 90 \mathrm{~mm} \mathrm{Hg}$ or use of antihypertensive (VI Diretrizes Brasileira de Hipertensao, 2010). ${ }^{b}$ One or more ATPIII criteria: total cholesterol $\geq 200 \mathrm{mg} / \mathrm{dL}$, LDL-c $\geq 130 \mathrm{mg} / \mathrm{dL}, \mathrm{HDL}-\mathrm{c}<40 \mathrm{mg} / \mathrm{dL}, \mathrm{TG} \geq 150 \mathrm{mg} / \mathrm{dL}, \mathrm{VLDL}-\mathrm{c} \geq 30$ $\mathrm{mg} / \mathrm{dL}$. 
below and above the 75th percentile and CRP levels were classified as low risk/moderate $(<3 \mathrm{mg} / \mathrm{L})$ and high risk $(\geq 3$ $\mathrm{mg} / \mathrm{L}$ ) according to the American Society of Cardiology and the Centers for Disease Control and Prevention (CDC) [31].

Student's $t$-test and analysis of variance (ANOVA) were used to estimate statistical significance between mean values of age and levels of lipid profile components, PTH, blood glucose, insulin, and adiponectin according to the categories of $25(\mathrm{OH}) \mathrm{D}$. Univariate analysis was used to cross-classified the categories of $25(\mathrm{OH}) \mathrm{D}(<30 \mathrm{ng} / \mathrm{mL}$ or $<75 \mathrm{nmol} / \mathrm{L}$ and $\geq 30$ $\mathrm{ng} / \mathrm{mL}$ or $\geq 75 \mathrm{nmol} / \mathrm{L}$ ) with demographic and behavioral variables and biochemical, anthropometric, clinical and body composition characteristics to generate odds ratios (ORs) with $95 \%$ confidence intervals (CIs) to guide interpretation. Multiple logistic regression models (enter method) were performed using CVD RF variables significantly associated with the categories of 25(OH)D in univariate analysis. To adjust the models, only the variables with $\mathrm{P} \leq 0.25$, biological plausibility, and epidemiological relevance were considered. The significance level for all tests was set at $5 \%(\mathrm{P}<0.05)$. Statistical analyses were performed using SPSS software version 22.0.

This study was approved by the Ethics Committee on Research With Human of the Ouro Preto Federal University. Participation in the study was entirely voluntary: workers consent and signed informed consent of each participant were obtained prior to the study.

\section{Results}

The average age of the 391 study participants was $36.1 \pm 7.3$ years (ranging from 20 to 57), and most of them with more than 8 years of education $(90 \%)$. Among workers, $51 \%$ had more than 5 years of work shift, and the majority were nonsmokers and non-alcoholic $(83.7 \%$ and $84.7 \%)$. The study population was largely sedentary, where only $22.3 \%$ reported doing physical activities outdoors for $10 \mathrm{~min}$ or more for a minimum of three times a week, but only $22.7 \%$ had excess visceral fat. The prevalence of hypertension and dyslipidemia was $30.8 \%$ and $74.2 \%$, respectively, and the prevalence of hypovitaminosis D (serum $25(\mathrm{OH}) \mathrm{D}$ below $30 \mathrm{ng} / \mathrm{mL}$ or 75 $\mathrm{nmol} / \mathrm{L})$ in this population was high $(73 \%)$. The prevalence of overweight (BMI: $25-29.9 \mathrm{~kg} / \mathrm{m}^{2}$ ) and obesity (BMI $\geq 30 \mathrm{~kg} /$ $\mathrm{m}^{2}$ ) was $48.4 \%$ and $17.2 \%$, respectively.

Table 1 shows the distribution of the categories of demographic and behavioral variables according to vitamin $\mathrm{D}$ levels observed among these workers. Workers whose blood had been collected in the summer $(29.7 \pm 8.1 \mathrm{ng} / \mathrm{mL}$ or $74.2 \mathrm{nmol} / \mathrm{L})$ had significantly higher vitamin $\mathrm{D}$ levels $(\mathrm{P}<0.0001)$ than that collected in the spring $(24.5 \pm 7.2 \mathrm{ng} / \mathrm{mL}$ or $61.2 \mathrm{nmol} / \mathrm{L})$.

Table 2 shows the biochemical, anthropometric, clinical and body composition characteristics according to levels of $25(\mathrm{OH}) \mathrm{D}$ regarded as insufficient and sufficient in this population. All anthropometric variables were significant enough for the insufficient vitamin D group $(<30 \mathrm{ng} / \mathrm{mL}$ or $75 \mathrm{nmol} / \mathrm{L})$, highlighting the waist/height ratio that had the highest value of OR 2.38 (95\% CI: 1.46 - 3.88). For body composition variables, visceral fat was significant with an OR of 2.9 (95\% CI:
1.46 - 5.75). Dyslipidemia had significantly lower vitamin D levels (OR: 2.7, 95\% CI: 1.6 - 4.3) than individuals with normal cholesterol levels and fractions, and triglycerides. Between the cholesterol fractions, only the HDL was not significant when comparing the sufficient and insufficient groups. Hyperglycemic workers had significantly lower levels of vitamin D than euglycemic workers $(\mathrm{P}<0.05)$.

The concentrations of biochemical variables were distributed in quartiles of $25(\mathrm{OH}) \mathrm{D}$ and there was a significant difference for all variables except for HDL-c and adiponectin (Table $3)$. Among the biochemical variables, as the levels of $25(\mathrm{OH})$ $\mathrm{D}$ increased, the levels of triglycerides, total cholesterol, LDL$\mathrm{c}$ and VLDL-c fractions, fasting glucose, fasting insulin, and PTH decreased. The same pattern was seen in the VFA, BMI, and systolic and diastolic blood pressure. Conversely, the HDL-c fraction followed a pattern increasing from quartiles 1 through 4.

A binary logistic regression model was created using the anthropometric, body composition, and biochemical variables adjusted for age and seasonality. The variables that remained significant were visceral fat, LDL-c, and triglycerides (Table 4). In relation to workers with sufficient levels of vitamin D, those with insufficient levels most often presented with excess visceral fat in the range $11-20 \mathrm{~cm}^{3}$ (OR: 2.4; 95\% CI: 1.1 5.2) with excess LDL-c above $160 \mathrm{mg} / \mathrm{dL}$ (OR: 5.9; $95 \%$ CI: 1.3 - 25.7), and excess triglycerides above $150 \mathrm{mg} / \mathrm{dL}$ (OR: $2.3 ; 95 \%$ CI: $1.3-4.0$ ).

Table 5 shows the modification of risk analysis adjusted for age and seasonality for the insufficient and sufficient groups with regard to the TG levels and VFA. Considering TG levels $<150 \mathrm{mg} / \mathrm{dL}$ and VFA $\leq 10 \mathrm{~cm}^{3}$ as the reference group, the risk of vitamin D insufficiency was 2.2 times higher $(95 \%$ CI: $1.23-3.83$ ) in the presence of only $\mathrm{TG} \geq 150 \mathrm{mg} / \mathrm{dL}$ and 2.0 times higher (95\% CI: $0.80-4.89)$ in the presence of only VFA $>10 \mathrm{~cm}^{3}$. The risk was 8.23 (95\% CI: $\left.2.38-28.51\right)$ in the presence of both factors. Risk modification analysis was adjusted for age and seasonality for the insufficient and sufficient groups for TG and LDL-c levels. Considering TG levels $<150 \mathrm{mg} / \mathrm{dL}$ and LDL-c $<160 \mathrm{mg} / \mathrm{dL}$ as the reference group, the risk of vitamin D insufficiency was 2.1 times higher $(95 \%$ CI: $1.2-3.5$ ) only in the presence of $\mathrm{TG} \geq 150 \mathrm{mg} / \mathrm{dL}$ and 3.51 times higher (95\% CI: $0.7-16.1)$ only in the presence of LDL-c $\geq 160 \mathrm{mg} / \mathrm{dL}$. It was $11.1(95 \% \mathrm{CI}: 1.4-84.2)$ in the presence of the two RFs.

\section{Discussion}

Our results show that $23 \%$ of the participants had deficiency and $50 \%$ for vitamin $\mathrm{D}$ insufficiency. Given that hypovitaminosis $\mathrm{D}$ includes both groups, this percentage reaches $73 \%$. The average of the $25(\mathrm{OH}) \mathrm{D}$ levels was low in this population, equal to $26.1 \mathrm{ng} / \mathrm{mL}(65.2 \mathrm{nmol} / \mathrm{L})$. A significant doseresponse pattern between hypovitaminosis $\mathrm{D}$ was observed $(25(\mathrm{OH}) \mathrm{D}<30 \mathrm{ng} / \mathrm{mL}$ or $75 \mathrm{nmol} / \mathrm{L})$ along with disturbances in lipid profile (triglycerides and LDL-c) and the visceral adiposity in this population.

The shift work schedule is subject to studies that show its 
Table 2. Biochemical Characteristics, Anthropometric, and Clinical Body Composition According to Levels of 25(OH)D

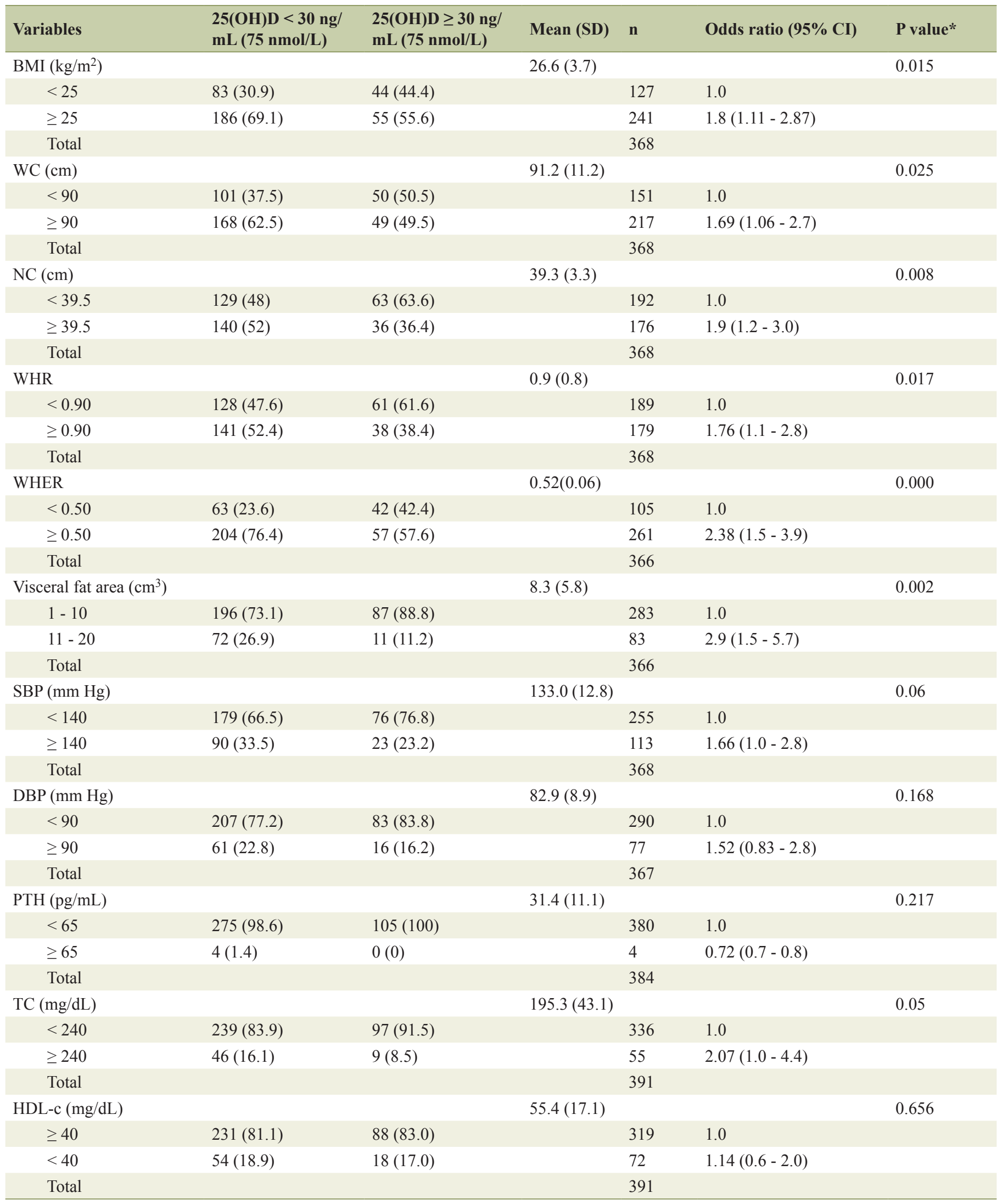


Table 2. Biochemical Characteristics, Anthropometric, and Clinical Body Composition According to Levels of 25(OH)D - (continued)

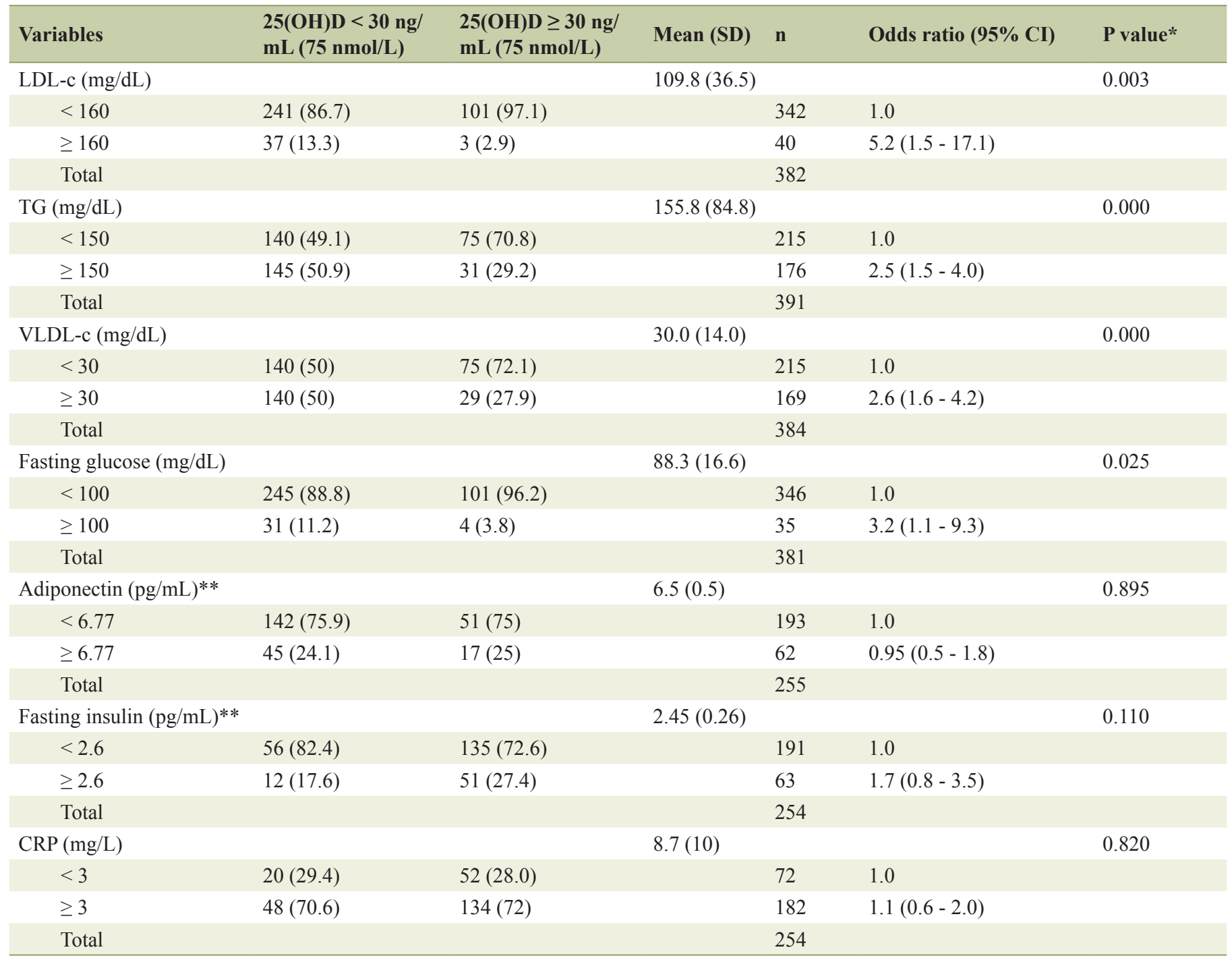

BMI: body mass index; WC: waist circumference; NC: neck circumference; WHR: waist-hip ratio; WHER: waist-height ratio; TC: total cholesterol; HDL-c: low-density lipoprotein cholesterol; LDL-c: high-density lipoprotein cholesterol; TG: triglycerides; VLDL-C: very low-density lipoprotein cholesterol; PTH: parathyroid hormone; CRP: C-reactive protein; SBP: systolic blood pressure; DBP: diastolic blood pressure. ${ }^{* *}$ Amount expressed in the logarithmic form. * $P$ value for Pearson's Chi-square $<0.05$ was considered significant.

link to increased risk of developing metabolic disorders mainly related to components of Metabolic Syndrome (MS) [19, 32] and the etiology of atherosclerosis [33]. In an earlier study in this same shift worker population, Ambrosim (2014) [34] found a high prevalence of RFs for MS, such as dyslipidemia, obesity, and overweight.

Shift work is identified as a contributor to a pro-atherogenic profile of cardiovascular risk by means of an unfavorable lipid profile [35], which is characterized by hypertriglyceridemia, decreased HDL, and the formation of smaller particles from the LDL-c, the known small LDL and dense (LDLpd). These factors together characterize the artherogenic lipid phenotype of MS [36].

Even though considered a subclinical event, hypovitaminosis $\mathrm{D}$ is recognized as one of the most important factors that influence the health of the skeleton and some chronic diseases such as CVD [4]. Hypovitamnosis D is associated with the intensity of exposure to sunlight, which is significantly reduced due to the occupational environment, especially in individuals working in shifts or in an enclosed room [13]. Some authors [37] found levels of $25(\mathrm{OH}) \mathrm{D}$ in shift workers similar to those observed in this study, indicating the occupational environment as an important factor influencing sunlight exposure.

Among the biochemical parameters significantly associated with vitamin D insufficiency, LDL-c merits close attention. Hypovitaminosis D was 5.9 times more frequent in individuals with levels above $160 \mathrm{mg} / \mathrm{dL}$ compared to those with lower levels. Excessive amounts of LDL-c in circulation participate in the formation of the atheroma after being modified by oxidation. Increased concentrations of LDL-c increase cardiovas- 
Table 3. Distribution of Serum Levels of Lipid Profile Components, PTH, Blood Glucose, Insulin, and Adiponectin According to the Quartile of $25(\mathrm{OH}) \mathrm{D}$ in the Group of Alternating Shift Workers in the Inconfidentes Region, Minas Gerais

\begin{tabular}{|c|c|c|c|c|c|}
\hline Variables & $\begin{array}{l}\text { Quartile } 1 \\
(0 \text { - } 19.9 \mathrm{ng} / \mathrm{mL}) \\
(0-49.9 \mathrm{nmol} / \mathrm{L})\end{array}$ & $\begin{array}{l}\text { Quartile } 2 \\
(20 \text { - } 24.6 \mathrm{ng} / \mathrm{mL}) \\
(50-61.1 \mathrm{nmol} / \mathrm{L})\end{array}$ & $\begin{array}{l}\text { Quartile } 3 \\
(24.7 \text { - } 29.7 \mathrm{ng} / \mathrm{mL}) \\
(61.2-74.2 \mathrm{nmol} / \mathrm{L})\end{array}$ & $\begin{array}{l}\text { Quartile } 4 \\
(29.8-60 \mathrm{ng} / \mathrm{mL}) \\
(74.3-150 \mathrm{nmol} / \mathrm{L})\end{array}$ & P value* \\
\hline TG (mg/dL) & $191.1 \pm 90.3^{\mathrm{a}}$ & $169.4 \pm 89.9^{\mathrm{a}}$ & $134.8 \pm 63.8^{\mathrm{b}}$ & $132.5 \pm 79.8^{b}$ & $<0.001$ \\
\hline TC (mg/dL) & $199.4 \pm 47.9^{\mathrm{a}, \mathrm{b}}$ & $202.4 \pm 41.3^{b}$ & $197.0 \pm 43.6^{\mathrm{a}, \mathrm{b}}$ & $183.7 \pm 38.1^{\mathrm{a}}$ & 0.010 \\
\hline HDL-c (mg/dL) & $52.2 \pm 17.2^{\mathrm{a}}$ & $54.6 \pm 15.5^{\mathrm{a}}$ & $56.6 \pm 18.0^{\mathrm{a}}$ & $57.8 \pm 17.6^{\mathrm{a}}$ & 0.109 \\
\hline LDL-c (mg/dL) & $111.0 \pm 37.2^{\mathrm{a}, \mathrm{b}}$ & $115.7 \pm 37.0^{\mathrm{a}}$ & $113.7 \pm 39.5^{\mathrm{a}}$ & $100.0 \pm 30.7^{b}$ & 0.011 \\
\hline VLDL-c (mg/dL) & $36.8 \pm 15.5^{\mathrm{a}}$ & $32.1 \pm 12.4^{\mathrm{a}}$ & $26.3 \pm 11.2^{b}$ & $25.3 \pm 13.7^{\mathrm{b}}$ & $<0.001$ \\
\hline BMI $\left(\mathrm{kg} / \mathrm{m}^{2}\right)$ & $27.5 \pm 2.8^{a}$ & $28.0 \pm 4.2^{\mathrm{a}}$ & $25.5 \pm 3.5^{b}$ & $25.5 \pm 3.3^{b}$ & $<0.001$ \\
\hline $\operatorname{VFA}\left(\mathrm{cm}^{3}\right)$ & $9.2 \pm 3.0^{\mathrm{a}}$ & $9.1 \pm 3.6^{\mathrm{a}}$ & $7.1 \pm 2.8^{b}$ & $7.8 \pm 9.7^{b}$ & $<0.001$ \\
\hline PTH (pg/mL) & $35.4 \pm 13.5^{\mathrm{a}}$ & $31.3 \pm 10.6^{\mathrm{b}}$ & $29.6 \pm 9.1^{\mathrm{b}}$ & $29.9 \pm 10.3^{b}$ & 0.001 \\
\hline $\mathrm{FG}(\mathrm{mg} / \mathrm{dL})$ & $93.2 \pm 26.6^{\mathrm{a}}$ & $89.4 \pm 12.7^{\mathrm{a}, \mathrm{b}}$ & $86.6 \pm 14.0^{\mathrm{b}}$ & $85.0 \pm 8.0^{\mathrm{b}}$ & 0.004 \\
\hline $\mathrm{FI}(\mathrm{pg} / \mathrm{mL})^{*}$ & $2.5 \pm 0.2^{\mathrm{a}}$ & $2.5 \pm 0.3^{\mathrm{a}}$ & $2.4 \pm 0.3^{\mathrm{a}}$ & $2.4 \pm 0.3^{\mathrm{a}}$ & 0.017 \\
\hline $\operatorname{ADP}(\mathrm{pg} / \mathrm{mL})^{*}$ & $6.6 \pm 0.3^{\mathrm{a}}$ & $6.5 \pm 0.3^{\mathrm{a}}$ & $6.5 \pm 0.6^{\mathrm{a}}$ & $6.6 \pm 0.4^{\mathrm{a}}$ & 0.288 \\
\hline $\mathrm{SBP}(\mathrm{mm} \mathrm{Hg})$ & $135.9 \pm 12.6^{\mathrm{a}}$ & $134.0 \pm 12.4^{\mathrm{a}, \mathrm{b}}$ & $132.0 \pm 12.9^{\mathrm{a}, \mathrm{b}}$ & $130.3 \pm 12.8^{b}$ & 0.020 \\
\hline DBP (mm Hg) & $84.9 \pm 9.2^{\mathrm{a}}$ & $84.2 \pm 9.4^{\mathrm{a}}$ & $81.7 \pm 7.6^{\mathrm{a}, \mathrm{b}}$ & $80.8 \pm 8.8^{\mathrm{b}}$ & 0.003 \\
\hline
\end{tabular}

*Amount expressed in the logarithmic form one-way ANOVA TG. TC: total cholesterol; HDL-c: high-density lipoprotein cholesterol; LDL-c: low-density lipoprotein cholesterol; TG: triglycerides; VLDL-c: very low-density lipoprotein cholesterol; BMI: body mass index; VFA: visceral fat area; PTH: parathyroid hormone; FG: fasting glucose; FI: fasting insulin; ADP: adiponectin; SBP: systolic blood pressure; DBP: diastolic blood pressure. * $\mathrm{P}$ value for the ANOVA $<0.05$ was considered significant. ${ }^{\mathrm{a}, \mathrm{b}, \mathrm{c}}$ Equal letters indicate similar means Tukey post-test.

cular risk, but it is known that its size can be an even more important predictor. Hypovitaminosis D has been considered an independent RF for atherosclerosis and is associated with endothelial dysfunction and increased lipid peroxidation occurring in plasma lipoproteins and other mechanisms [38, 39]. A study that evaluated the effect of vitamin D supplementation on endothelial function showed favorable effects [40]. Also, the concentration of substances reactive to thiobarbituric acid (TBARS), which are used as indicators of lipid peroxidation, significantly decreased after supplementation in individuals with inadequate levels of $25(\mathrm{OH}) \mathrm{D}$. As the authors did not observe an association between flow-mediated dilation and $25(\mathrm{OH}) \mathrm{D}$ levels, it was concluded that the beneficial effects on endothelial function occurred due to a reduction in oxidative stress by $25(\mathrm{OH}) \mathrm{D}$. Therefore, hypovitaminosis $\mathrm{D}$ associated with high levels of LDL-c may predispose the emergence of dysfunction in vascular endothelium and increase CVD rates in alternating shift workers.

Another biochemical parameter independently associated with vitamin D insufficiency was TG. Hypovitaminosis D was 2.3 times more frequent in patients with TG levels greater than $150 \mathrm{mg} / \mathrm{dL}$ than in those with lower levels. There are some mechanisms suggested to explain the reduction of TG levels mediated by $25(\mathrm{OH}) \mathrm{D}$. The first mechanism is related to the function of classical vitamin $\mathrm{D}$ to increase the absorption of calcium via the intestines with consequent increase of its plasma levels. The elevation of serum calcium decreases hepatic TG synthesis and secretion through its suppressive effect on a TG microsomal transfer protein known as MTP (microsomal triglyceride transfer protein) [41]. The second mechanism relates to vitamin D suppressive effect on PTH concentration in serum. The post-heparin lipase activity is reduced by high

Table 4. Risk Factors Adjusted for Age and Seasonality for Hypovitaminosis D $(25(\mathrm{OH}) \mathrm{D}<30 \mathrm{ng} / \mathrm{mL}$ or $75 \mathrm{nmol} / \mathrm{L})$ in Alternating Shift Workers, Minas Gerais, Brazil

\begin{tabular}{|c|c|c|c|c|}
\hline Variables & Crude odds ratio (95\% CI) & P value & Adjusted odds ratio* (95\% CI) & P value \\
\hline \multicolumn{5}{|c|}{ Visceral fat area $\left(\mathrm{cm}^{3}\right)$} \\
\hline $11-20$ & $2.9(1.5-5.7)$ & 0.002 & $2.4(1.1-5.2)$ & 0.037 \\
\hline \multicolumn{5}{|c|}{ LDL-cholesterol level (mg/dL) } \\
\hline$\geq 160$ & $5.2(1.5-17.1)$ & 0.003 & $5.9(1.3-25.7)$ & 0.018 \\
\hline \multicolumn{5}{|c|}{$\begin{array}{l}\text { Triglycerides } \\
\text { level (mg/dL) }\end{array}$} \\
\hline$\geq 150$ & $2.5(1.5-4.0)$ & 0.000 & $2.3(1.3-4.0)$ & 0.003 \\
\hline
\end{tabular}

Cl: confidence interval. *Adjusting for age and seasonality. 
Table 5. Bivariate Association of Risk for Hypovitaminosis D Between Serum Levels of Triglycerides (TG) >150 md/dL, Visceral Fat Area (VFA) $11-20 \mathrm{~cm}^{3}$ and LDL-c > $160 \mathrm{mg} / \mathrm{dL}$

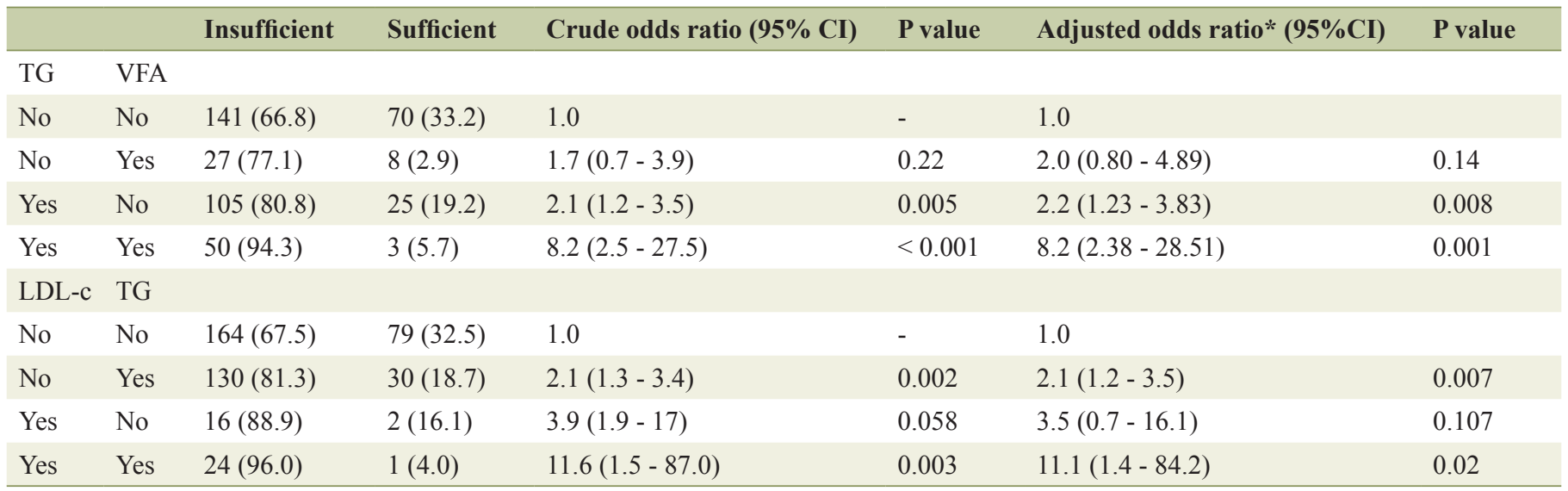

Cl: confidence interval; TG: triglycerides; VFA: visceral fat area; LDL-c: high density lipoprotein. *Adjusting for age and seasonality.

concentrations of PTH and low serum PTH levels can reduce TG levels via enhanced peripheral removal [41]. In addition, two other mechanisms have also been implicated. Vitamin D increases the expression of VLDL-c receptors in some kinds of cells [42] promoting increased uptake of TG. Finally, insulin resistance may explain the association between $25(\mathrm{OH}) \mathrm{D}$ and TG: when vitamin D deficiency is present, it increases the risk of insulin resistance [43], which in turn is associated with an increase in VLDL-c and TG.

In the present study, hypovitaminosis D was 11 times more common in individuals with high concomitant levels of LDL-c and TG compared to no change in these factors and much more frequently than in the presence of these factors alone $\left(\mathrm{OR}_{\mathrm{TG}}=\right.$ 2.1; $\left.\mathrm{OR}_{\mathrm{LDL}-\mathrm{c}}=3.5\right)$. Vitamin $\mathrm{D}$ appears to have an effect on the regulation of lipid profile and is considered by some authors as one of the mechanisms that explain its relationship with the DCV [44]. Some observational studies claim that low levels of vitamin D are associated with an unfavorable lipid profile [14], but some clinical studies do not confirm these findings [14]. Gonzalez et al (2014) [16] found an inverse relationship between deficient levels of $25(\mathrm{OH}) \mathrm{D}(<20 \mathrm{ng} / \mathrm{mL}$ or $50 \mathrm{nmol} / \mathrm{L}))$ and hypertriglyceridemia. However, no association with dyslipidemia was observed in this study. Yet other authors [45] found similar results to our study, finding a significant inverse association between 25(OH)D and LDL-c and TG.

Additionally, the concomitant presence of excess visceral fat and hypertriglyceridemia indicated increased risk of hypovitaminosis D (OR: 8.2) compared with the absence of those factors and much higher when in the presence of these factors separately $\left(\mathrm{OR}_{\mathrm{TG}}=2.2 ; \mathrm{OR}_{\mathrm{VFA}}=2.0\right)$. Visceral adiposity is another important factor involved in the etiology of atherogenic lipid phenotype present in the MS, which is considered the most pathogenic compartment and most often associated with the secretion of adipokines, among other factors [36]. Furthermore, in adults, the accumulation of visceral fat is strongly correlated with several other cardiovascular RFs such as hypertension, hypertriglyceridemia, impaired fasting glucose, MS, and insulin resistance [46-48]. Currently among the studies that aimed to assess the relationship of low levels of $25(\mathrm{OH}) \mathrm{D}$ with obesity, few have included direct measurements of adiposity. However, it is still difficult to establish the pattern of adiposity that affects more potential levels of vitamin D. More research is needed to explore these potential relationships.

Some limitations should be considered in this study, such as the adopted cross-sectional design, which cannot establish a causal relationship between the analyzed factors and hypovitaminosis $\mathrm{D}$. The absence of information on the use of sunscreen, along with the intake of vitamin D in the diet, could have influenced the low levels of vitamin $\mathrm{D}$ in this population. Finally, a third limiting factor is that using a single measurement of serum levels of $25(\mathrm{OH}) \mathrm{D}$ can only reflect recent exposure, not taking into account intra-individual seasonal variations, which may be present.

\section{Conclusion}

Our results suggest that alternate shift mine workers are exposed to excess body weight and dyslipidemia, and that these factors constitute strong predictors of hypovitaminosis D. Therefore, it is necessary to assess whether an intervention in the vitamin D status, combined with behavioral changes such as diet and physical activity, could influence the reduction of atherogenic lipid phenotype of the metabolic syndrome, thus contributing to an improvement in the health of this population.

\section{Acknowledgments}

The authors are grateful for the technical assistance of Cristina de Oliveira Lisboa Pereira and Cassio Zumerle Masioli. This work was supported by the Federal University of Ouro Preto (UFOP); the National Council for Scientific and Technological Development (CNPq); the Foundation for Research Support in Minas Gerais (FAPEMIG); and Gorceix Foundation (Ouro Preto, MG). 


\section{Conflicts of Interest}

The authors declare no conflict of interests.

\section{References}

1. Rosen CJ, Adams JS, Bikle DD, Black DM, Demay MB, Manson JE, Murad MH, et al. The nonskeletal effects of vitamin D: an Endocrine Society scientific statement. Endocr Rev. 2012;33(3):456-492.

2. Norman AW. From vitamin D to hormone D: fundamentals of the vitamin D endocrine system essential for good health. Am J Clin Nutr. 2008;88(2):491S-499S.

3. Ross AC, Manson JE, Abrams SA, Aloia JF, Brannon PM, Clinton SK, Durazo-Arvizu RA, et al. The 2011 report on dietary reference intakes for calcium and vitamin D from the Institute of Medicine: what clinicians need to know. J Clin Endocrinol Metab. 2011;96(1):53-58.

4. Martins D, Wolf M, Pan D, Zadshir A, Tareen N, Thadhani R, Felsenfeld A, et al. Prevalence of cardiovascular risk factors and the serum levels of 25-hydroxyvitamin D in the United States: data from the Third National Health and Nutrition Examination Survey. Arch Intern Med. 2007;167(11):1159-1165.

5. Brandenburg VM, Vervloet MG, Marx N. The role of vitamin D in cardiovascular disease: from present evidence to future perspectives. Atherosclerosis. 2012;225(2):253263.

6. Abu el Maaty MA, Gad MZ. Vitamin D deficiency and cardiovascular disease: potential mechanisms and novel perspectives. J Nutr Sci Vitaminol (Tokyo). 2013;59(6):479488.

7. Chung JY, Hong SH. Vitamin D status and its association with cardiometabolic risk factors in Korean adults based on a 2008-2010 Korean National Health and Nutrition Examination Survey. Nutr Res Pract. 2013;7(6):495-502.

8. Kilkkinen A, Knekt P, Aro A, Rissanen H, Marniemi J, Heliovaara M, Impivaara O, et al. Vitamin D status and the risk of cardiovascular disease death. Am J Epidemiol. 2009;170(8):1032-1039.

9. Ding C, Gao D, Wilding J, Trayhurn P, Bing C. Vitamin D signalling in adipose tissue. Br J Nutr. 2012;108(11):19151923.

10. Wortsman J, Matsuoka LY, Chen TC, Lu Z, Holick MF. Decreased bioavailability of vitamin D in obesity. Am J Clin Nutr. 2000;72(3):690-693.

11. Wahl DA, Cooper C, Ebeling PR, Eggersdorfer M, Hilger J, Hoffmann K, Josse R, et al. A global representation of vitamin $\mathrm{D}$ status in healthy populations. Arch Osteoporos. 2012;7:155-172.

12. Mithal A, Wahl DA, Bonjour JP, Burckhardt P, DawsonHughes B, Eisman JA, El-Hajj Fuleihan G, et al. Global vitamin $\mathrm{D}$ status and determinants of hypovitaminosis $\mathrm{D}$. Osteoporos Int. 2009;20(11):1807-1820.

13. Ward M, Berry DJ, Power C, Hypponen E. Working patterns and vitamin D status in mid-life: a cross-sectional study of the 1958 British birth cohort. Occup Environ
Med. 2011;68(12):902-907.

14. Jorde R, Grimnes G. Vitamin D and metabolic health with special reference to the effect of vitamin D on serum lipids. Prog Lipid Res. 2011;50(4):303-312.

15. Zittermann A, Gummert JF, Borgermann J. The role of vitamin D in dyslipidemia and cardiovascular disease. Curr Pharm Des. 2011;17(9):933-942.

16. Gonzalez MI, Morcillo S, Rojo G, Rubio E, GutierrezRepiso C, Soriguer F. Lipids and vitamin D levels. Atherosclerosis. 2014;235(2): e273-e274.

17. Vimaleswaran KS, Berry DJ, Lu C, Tikkanen E, Pilz S, Hiraki LT, Cooper JD, et al. Causal relationship between obesity and vitamin D status: bi-directional Mendelian randomization analysis of multiple cohorts. PLoS Med. 2013;10(2):e1001383.

18. Karlsson BH, Knutsson AK, Lindahl BO, Alfredsson LS. Metabolic disturbances in male workers with rotating three-shift work. Results of the WOLF study. Int Arch Occup Environ Health. 2003;76(6):424-430.

19. Kawabe Y, Nakamura Y, Kikuchi S, Murakami Y, Tanaka T, Takebayashi T, Okayama A, et al. Relationship between shift work and clustering of the metabolic syndrome diagnostic components. J Atheroscler Thromb. 2014;21(7):703-711.

20. World Health Organization. AUDIT: The alcohol use disorders identification test: guidelines for use in a primary care 2nd ed. Genebra: World Health Organization. 2001;40.

21. Fagerstrom KO. Measuring degree of physical dependence to tobacco smoking with reference to individualization of treatment. Addict Behav. 1978;3(3-4):235-241.

22. Matsudo S, Araujo T, Matsudo V, Andrade D, Andrade E, Oliveira LC, et al. Questionario Internacional de Atividade Fisica (IPAQ): estudo de validade e reprodutibilidade no Brasil. Atividade Fisica \& Saude. 2001;6(2):518.

23. Sociedade Brasileira de Cardiologia/Sociedade Brasileira de Hipertensao/Sociedade Brasileira de Nefrologia. VI Diretrizes Brasileiras de Hipertensao. Arq Bras Cardiol. 2010;95(1 supl.1):1-51.

24. Obesity: preventing and managing the global epidemic. Report of a WHO consultation. World Health Organ Tech Rep Ser. 2000;894:i-xii, 1-253.

25. Physical status: the use and interpretation of anthropometry. Report of a WHO Expert Committee. World Health Organ Tech Rep Ser. 1995;854:1-452.

26. Maeda SS, Borba VZ, Camargo MB, Silva DM, Borges JL, Bandeira F, Lazaretti-Castro M. Recommendations of the Brazilian Society of Endocrinology and Metabology (SBEM) for the diagnosis and treatment of hypovitaminosis D. Arq Bras Endocrinol Metabol. 2014;58(5):411-433.

27. Friedewald WT, Levy RI, Fredrickson DS. Estimation of the concentration of low-density lipoprotein cholesterol in plasma, without use of the preparative ultracentrifuge. Clin Chem. 1972;18(6):499-502.

28. Xavier HT, Izar MC, Faria Neto JR, Assad MH, Rocha VZ, Sposito AC, Fonseca FA, et al. [V Brazilian Guidelines on Dyslipidemias and Prevention of Atherosclerosis]. Arq Bras Cardiol. 2013;101(4 Suppl 1):1-20. 
29. Third Report of the National Cholesterol Education Program (NCEP) Expert Panel on Detection, Evaluation, and Treatment of High Blood Cholesterol in Adults (Adult Treatment Panel III) final report. Circulation. 2002;106(25):3143-3421.

30. IDF (International Diabetes Federation). (2005)Consensus worldwide definition of the metabolic syndrome. http://www.idf.org/metabolic_syndrome (12/01/2015).

31. Pearson TA, Mensah GA, Alexander RW, Anderson JL, Cannon RO, 3rd, Criqui M, Fadl YY, et al. Markers of inflammation and cardiovascular disease: application to clinical and public health practice: A statement for healthcare professionals from the Centers for Disease Control and Prevention and the American Heart Association. Circulation. 2003;107(3):499-511.

32. De Bacquer D, Van Risseghem M, Clays E, Kittel F, De Backer G, Braeckman L. Rotating shift work and the metabolic syndrome: a prospective study. Int J Epidemiol. 2009;38(3):848-854.

33. Haupt CM, Alte D, Dorr M, Robinson DM, Felix SB, John U, Volzke H. The relation of exposure to shift work with atherosclerosis and myocardial infarction in a general population. Atherosclerosis. 2008;201(1):205-211.

34. Ambrosim TV. Fenotipos para a sindrome metabolica em trabalhadores de turnos alternantes de uma mineradora na regiao dos Inconfidentes-MG. 111p. Dissertacao de mestrado. Universidade Federal de Ouro Preto. 2014.

35. Dochi M, Suwazono Y, Sakata K, Okubo Y, Oishi M, Tanaka K, Kobayashi E, et al. Shift work is a risk factor for increased total cholesterol level: a 14-year prospective cohort study in 6886 male workers. Occup Environ Med. 2009;66(9):592-597.

36. Fox CS, Massaro JM, Hoffmann U, Pou KM, MaurovichHorvat P, Liu CY, Vasan RS, et al. Abdominal visceral and subcutaneous adipose tissue compartments: association with metabolic risk factors in the Framingham Heart Study. Circulation. 2007;116(1):39-48.

37. Maeda SS, Kunii IS, Hayashi L, Lazaretti-Castro M. The effect of sun exposure on 25-hydroxyvitamin D concentrations in young healthy subjects living in the city of Sao Paulo, Brazil. Braz J Med Biol Res. 2007;40(12):1653-
1659.

38. Brewer LC, Michos ED, Reis JP. Vitamin D in atherosclerosis, vascular disease, and endothelial function. Curr Drug Targets. 2011;12(1):54-60.

39. Weng S, Sprague JE, Oh J, Riek AE, Chin K, Garcia M, Bernal-Mizrachi C. Vitamin D deficiency induces high blood pressure and accelerates atherosclerosis in mice. PLoS One. 2013;8(1):e54625.

40. Tarcin O, Yavuz DG, Ozben B, Telli A, Ogunc AV, Yuksel M, Toprak A, et al. Effect of vitamin D deficiency and replacement on endothelial function in asymptomatic subjects. J Clin Endocrinol Metab. 2009;94(10):4023-4030.

41. Cho HJ, Kang HC, Choi SA, Ju YC, Lee HS, Park HJ. The possible role of $\mathrm{Ca} 2+$ on the activation of microsomal triglyceride transfer protein in rat hepatocytes. Biol Pharm Bull. 2005;28(8):1418-1423.

42. Jouni ZE, Winzerling JJ, McNamara DJ. 1,25-Dihydroxyvitamin D3-induced HL-60 macrophages: regulation of cholesterol and LDL metabolism. Atherosclerosis. 1995;117(1):125-138.

43. Pittas AG, Dawson-Hughes B. Vitamin D and diabetes. J Steroid Biochem Mol Biol. 2010;121(1-2):425-429.

44. Saedisomeolia A, Taheri E, Djalali M, Moghadam AM, Qorbani M. Association between serum level of vitamin D and lipid profiles in type 2 diabetic patients in Iran. Journal of Diabetes and Metabolic Disorders, 2014;13(1):7.

45. Karhapaa P, Pihlajamaki J, Porsti I, Kastarinen M, Mustonen J, Niemela O, Kuusisto J. Diverse associations of 25-hydroxyvitamin D and 1,25-dihydroxy-vitamin D with dyslipidaemias. J Intern Med. 2010;268(6):604-610.

46. Despres JP. Body fat distribution and risk of cardiovascular disease: an update. Circulation. 2012;126(10):13011313.

47. Van Gaal LF, Mertens IL, De Block CE. Mechanisms linking obesity with cardiovascular disease. Nature. 2006;444(7121):875-880.

48. Gast KB, Smit JW, den Heijer M, Middeldorp S, Rippe $\mathrm{RC}$, le Cessie S, de Koning EJ, et al. Abdominal adiposity largely explains associations between insulin resistance, hyperglycemia and subclinical atherosclerosis: the NEO study. Atherosclerosis. 2013;229(2):423-429. 